\title{
OPEN Synthesis and in vitro assay of hydroxyxanthones as antioxidant and anticancer agents
}

Nela Fatmasari ${ }^{1}$, Yehezkiel Steven Kurniawan ${ }^{1}$, Jumina Jumina ${ }^{1 \bowtie}$, Chairil Anwar Yoga Priastomo ${ }^{1}$, Harno Dwi Pranowo ${ }^{1}$, Abdul Karim Zulkarnain ${ }^{2}$ \& Eti Nurwening Sholikhah ${ }^{3}$

In the present work, three hydroxyxanthones were synthesized in $11.15-33.42 \%$ yield from 2,6-dihydroxybenzoic acid as the starting material. The chemical structures of prepared hydroxyxanthones have been elucidated by using spectroscopic techniques. Afterward, the hydroxyxanthones were evaluated as antioxidant agents through radical scavenging assay; and anticancer agents through in vitro assays against WiDr, MCF-7, and HeLa cancer cell lines. Hydroxyxanthone $3 \mathrm{~b}$ was categorized as a strong antioxidant agent $\left(\mathrm{IC}_{50}=349 \pm 68 \mu \mathrm{M}\right)$, while the other compounds were categorized as moderate antioxidant agents $\left(\mathrm{IC}_{50}>500 \mu \mathrm{M}\right)$. On the other hand, hydroxyxanthone 3 a exhibited the highest anticancer activity $\left(\mathrm{IC}_{50}=184 \pm 15 \mu \mathrm{M}\right)$ and the highest selectivity ( $\mathrm{SI}=18.42$ ) against MCF-7 cancer cells. From the molecular docking study, it was found that hydroxyxanthone $3 a$ interacted with the active sites of Topoisomerase II protein through Hydrogen bonding with DG13 and $\pi-\pi$ stacking interactions with DA12 and DC8. These findings revealed that hydroxyxanthones are potential candidates to be developed as antioxidant and anticancer agents in the future.

Oxidative stress diseases have been receiving great attention due to their harmful, severe, and unfavorable effects on the human body ${ }^{1}$. Several fatal diseases such as cancer, arthritis, cardiovascular, and neurodegenerative diseases are generated by oxidative stress that damages human tissue and organs ${ }^{2}$. Free radicals are reported as the main factor in the production of oxidative stress in the human body. Free radicals are very reactive; thus, they react rapidly with biomolecules such as DNA and affect cell metabolism ${ }^{3}$. Additionally, free radicals are also responsible for cholesterol and atherosclerosis deposition inside the blood vessels ${ }^{4}$. Therefore, researchers are making extensive efforts to prevent and deactivate the free radicals before damaging the cell function ${ }^{5}$.

Usage of antioxidant agents is the most straightforward approach to deactivate the free radicals ${ }^{6}$. Almost all antioxidant agents are composed of phenolic compounds because phenolic compounds are able to generate hydrogen donor and electron delocalization mechanisms to suppress the formation of oxidative stress ${ }^{7}$. Several natural and synthetic antioxidant agents such as chalcone, indole-3-acetamide, cadmium-bismuth microsphere, indazole, and salicylhydrazidehydrazone derivatives have been evaluated; however, their chemical synthesis is not easy, and their antioxidant activity is still unsatisfactory ${ }^{8-12}$.

Almost $80-95 \%$ of antioxidant and anticancer agents consist of a heterocyclic structure. Among the heterocyclic compounds, xanthone derivatives with a dibenzo- $\gamma$-pyrone skeleton exhibit unique physicochemical properties $^{13-16}$. Furthermore, xanthones display broad pharmacological activities, which are remarkable to be further developed for the drug research ${ }^{17-21}$. Xanthone could be obtained from various plants, such as Symphonia globulifera and Garcinia mangostana ${ }^{22,23}$. Nevertheless, the isolation process is very complicated to obtain the desired xanthone derivatives in high purity. Furthermore, the isolation and purification of xanthones require a large volume of organic solvents in a time-consuming process ${ }^{24}$. Therefore, the synthesis of xanthone is much attractive to be developed to afford xanthone derivatives in a higher yield within a faster research period. Moreover, it is possible to obtain xanthone derivatives with specific functional groups at a certain position by using a synthesis reaction, which may not be found in natural sources ${ }^{18}$.

${ }^{1}$ Department of Chemistry, Faculty of Mathematics and Natural Science, Universitas Gadjah Mada, Yogyakarta 55281, Indonesia. '2Department of Pharmaceutical Technology, Faculty of Pharmacy, Universitas Gadjah Mada, Yogyakarta 55281, Indonesia. ${ }^{3}$ Department of Pharmacology and Therapy, Faculty of Medicine, Public Health, and Nursing, Universitas Gadjah Mada, Yogyakarta 55281, Indonesia. ${ }^{\circledR}$ email: jumina@ugm.ac.id 
The synthesis of xanthone was firstly established in 1892 by Michael and Kostanecki by reacting phenol, acetic acid-o-hydroxybenzoate, and acetic anhydride. Unfortunately, this method generates an unfavorable side reaction; thus, the obtained yield was very low. Eaton's reagent (a mixture of $\mathrm{P}_{2} \mathrm{O}_{5}$ and $\mathrm{CH}_{3} \mathrm{SO}_{3} \mathrm{H}$ ) has recently been introduced to give a higher yield for xanthone derivatives ${ }^{25}$. For example, Zhou et al. successfully synthesized 1,3-dihydroxydinitroxanthone and 7-(2,4-diphenyl)-1,3-dihydroxyxanthone in up to 76\% yield; however, their antioxidant activity was still lower compared to the commercial antioxidant agents ${ }^{26}$. Because of that, synthesis and modification of other xanthone derivatives are important to find the active antioxidant agents to be used for commercial purposes.

Xanthone, benzylhydrazone, and quinoxaline derivatives have been reported to give remarkable anticancer activities $^{16,27,28}$. Hydroxyxanthones exhibit good anticancer activity against lung, breast, hepatoma, cervical, colorectal, and other cancer cell lines ${ }^{16,29}$. Hydroxyxanthones could lead to cell apoptosis by stimulating the caspase enzyme ${ }^{30}$. Furthermore, hydroxyxanthones are able to inhibit Topoisomerase II protein by intercalation mechanism on the DNA cleavage sites ${ }^{31}$. This anticancer mechanism occurred as the hydroxyxanthones were constructed by three fused aromatic systems, which were reported as the essential pharmacophoric feature of Topoisomerase II inhibitors ${ }^{32}$. Furthermore, the three fused aromatic structure of hydroxyxanthones is similar to doxorubicin and mitoxantrone as standard DNA intercalators ${ }^{28}$. Therefore, hydroxyxanthones are potential to be further investigated as anticancer agents.

In our previous work, several hydroxyxanthone derivatives, i.e., 1,3-dihydroxyxanthone, 3,4-dihydroxyxanthone, 3,6-dihydroxyxanthone, 1,3,6-trihydroxyxanthone, and 3,4,6-trihydroxyxanthone have been synthesized and evaluated as the anticancer agent against WiDr cancer cell line ${ }^{33}$. In continuation of our previous research, we synthesized other hydroxyxanthone derivatives to give a broader map of their antioxidant and anticancer activities through in vitro and molecular docking studies. In this work, three hydroxyxanthone derivatives, i.e., 1,3,8-trihydroxyxanthone (3a), 1,6-dihydroxyxanthone (3b), and 1,5,6-trihydrokxyxanthone (3c) were prepared from 2,6-dihydroxybenzoic acid with phloroglucinol, resorcinol, and pyrogallol, respectively. The chemical structure of these hydroxyxanthones was elucidated using Fourier transform infrared (FTIR) spectrophotometer, mass spectrometry (MS), and nuclear magnetic resonance (NMR) spectrometers. These compounds were evaluated as antioxidant and anticancer agents through in vitro assay using 1,1-diphenylpicryl-2-hydrazyl (DPPH) and 3-(4,5-dimethylthiazol-2-yl)-2,5-diphenyltetrazolium bromide (MTT) methods, respectively. The inhibition mechanism of the most active anticancer agent against Topoisomerase II protein was further studied through a molecular docking study.

\section{Materials and methods}

Materials. The chemicals used in the synthesis, i.e., 2,6-dihydroxybenzoic acid $\left(\mathrm{C}_{7} \mathrm{H}_{6} \mathrm{O}_{4}\right)$, phloroglucinol $\left(\mathrm{C}_{6} \mathrm{H}_{6} \mathrm{O}_{3}\right)$, resorcinol $\left(\mathrm{C}_{6} \mathrm{H}_{6} \mathrm{O}_{2}\right)$, pyrogallol $\left(\mathrm{C}_{6} \mathrm{H}_{6} \mathrm{O}_{3}\right)$, Eaton's reagent $\left(\mathrm{P}_{2} \mathrm{O}_{5}, \mathrm{CH}_{3} \mathrm{SO} \mathrm{H}\right), \mathrm{DPPH}\left(\mathrm{C}_{18} \mathrm{H}_{12} \mathrm{~N}_{5} \mathrm{O}_{6}\right)$, $n$-hexane $\left(\mathrm{C}_{6} \mathrm{H}_{14}\right)$, ethyl acetate $\left(\mathrm{C}_{4} \mathrm{H}_{8} \mathrm{O}_{2}\right)$, and methanol $\left(\mathrm{CH}_{3} \mathrm{OH}\right)$ were purchased from Merck in pro analytical grade. In addition, butylated hydroxytoluene $\left(B H T, \mathrm{C}_{15} \mathrm{H}_{24} \mathrm{O}\right)$ and $\mathrm{MTT}\left(\mathrm{C}_{18} \mathrm{H}_{17} \mathrm{~N}_{5} \mathrm{~S}\right)$ were obtained from Aldrich in pro analytical grade.

Preparation of hydroxyxanthones. A mixture of 2,4-dihydroxybenzoic acid (3.66 g, $15.0 \mathrm{mmol})$, the substituted phenol (phloroglucinol, resorcinol, and pyrogallol) $(15.0 \mathrm{mmol}, 1$ equiv.), and Eaton's reagent $(8.00 \mathrm{~mL})$ was heated at $80-85^{\circ} \mathrm{C}$ for $3 \mathrm{~h}$. Then, the mixture was allowed to reach room temperature, and the mixture was poured with cooled water $(50 \mathrm{~mL})$. The resulting solid residue was collected by filtration, washed with water until neutral, dried, and then purified by preparative thin layer chromatography. In the preparative thin-layer chromatography, silica was used as the stationary phase, while a mixture of $n$-hexane and ethyl acetate $1: 1 \mathrm{v} / \mathrm{v}$ was used as the mobile phase to afford the target compound. The products were then characterized using FTIR (Shimadzu-Prestige 21), MS (Shimadzu QP-2010S), ${ }^{1} \mathrm{H}-$ and ${ }^{13} \mathrm{C}-\mathrm{NMR}$ (JEOL JNMECA $500 \mathrm{MHz}$ ) spectrometers.

1,3,8-trihydroxyxanthones (3a). The compound 3a was obtained as a yellow solid in $16.14 \%$ yield. m.p. 239-240 ${ }^{\circ} \mathrm{C}$. FTIR (KBr) v/cm ${ }^{-1}: 3448(\mathrm{O}-\mathrm{H}), 1612(\mathrm{C}=\mathrm{O}), 1418(\mathrm{C}=\mathrm{C}), 1296(\mathrm{C}-\mathrm{O}-\mathrm{C}) .{ }^{1} \mathrm{H}-\mathrm{NMR}\left(\mathrm{CD}_{3} \mathrm{OD}\right.$, $500 \mathrm{MHz}) \delta / \mathrm{ppm}=6.09(1 \mathrm{H}, \mathrm{d}, J=2.07 \mathrm{~Hz}, \mathrm{H} 7), 6.20(1 \mathrm{H}, \mathrm{d}, J=2.07 \mathrm{~Hz}, \mathrm{H} 5), 6.64(1 \mathrm{H}, \mathrm{d}, J=8.50 \mathrm{~Hz}, \mathrm{H} 2), 6.78$ $(1 \mathrm{H}, \mathrm{d}, J=8.50 \mathrm{~Hz}, \mathrm{H} 4), 7.49(1 \mathrm{H}, \mathrm{t}, J=8.36 \mathrm{~Hz}, \mathrm{H} 3) .{ }^{13} \mathrm{C}-\mathrm{NMR}\left(\mathrm{CD}_{3} \mathrm{OD}, 125 \mathrm{MHz}\right) \delta / \mathrm{ppm}=95.8(\mathrm{C} 7), 100.0$ (C5), 107.9 (C8a), 111.4 (C8b), 115.9 (C4), 128.4 (C2), 137.6 (C3), 157.4 (C4a), 159.4 (C4b), 162.3 (C1), 164.2 (C6), 169.9 (C8), 185.1 (C9). MS $m / z=244[\mathrm{M}]^{+}$.

1,6-dihydroxyxanthones (3b). This compound was obtained as a yellow solid in $33.42 \%$ yield; m.p. $248-249^{\circ} \mathrm{C}$. FTIR (KBr) v/ $\mathrm{cm}^{-1}: 3425(\mathrm{O}-\mathrm{H}), 1604(\mathrm{C}=\mathrm{O}), 1465(\mathrm{C}=\mathrm{C}), 1273(\mathrm{C}-\mathrm{O}-\mathrm{C}) .{ }^{1} \mathrm{H}-\mathrm{NMR}\left(\mathrm{CD}_{3} \mathrm{OD}, 500 \mathrm{MHz}\right) \delta /$ $\mathrm{ppm}=6.67(1 \mathrm{H}, \mathrm{dd}, J=2.15$ and $8.81 \mathrm{~Hz}, \mathrm{H} 7), 6.71(1 \mathrm{H}, \mathrm{d}, J=2.15 \mathrm{~Hz}, \mathrm{H} 5), 6.81(1 \mathrm{H}, \mathrm{dd}, J=8.31$ and $2.23 \mathrm{~Hz}$, $\mathrm{H} 2), 6.85(1 \mathrm{H}, \mathrm{dd}, J=8.31$ and $2.23 \mathrm{~Hz}, \mathrm{H} 4), 7.52(1 \mathrm{H}, \mathrm{t}, J=8.31 \mathrm{~Hz}, \mathrm{H} 3), 7.99(1 \mathrm{H}, \mathrm{d}, J=8.81 \mathrm{~Hz}, \mathrm{H} 8) .{ }^{13} \mathrm{C}-\mathrm{NMR}$ $\left(\mathrm{CD}_{3} \mathrm{OD}, 125 \mathrm{MHz}\right) \delta / \mathrm{ppm}=102.7(\mathrm{C} 5), 107.3(\mathrm{C} 4), 108.8(\mathrm{C} 8 \mathrm{~b}), 110.5(\mathrm{C} 2), 113.2(\mathrm{C} 8 \mathrm{a}), 115.4(\mathrm{C} 7), 127.9(\mathrm{C} 8)$, 136.6 (C3), 157.2 (C4a), 159.4 (C4b), 162.4 (C6), 167.5 (C1), 181.9 (C9). MS $m / z=228[\mathrm{M}]^{+}$.

1,5,6-trihydroxyxanthones $(3 \mathrm{c})$. This compound was obtained as a yellow solid in $11.15 \%$ yield. m.p. 251-252 ${ }^{\circ} \mathrm{C}$. FTIR $(\mathrm{KBr}) \mathrm{v} / \mathrm{cm}^{-1}: 3448(\mathrm{O}-\mathrm{H}), 1604(\mathrm{C}=\mathrm{O}), 1458(\mathrm{C}=\mathrm{C}), 1273(\mathrm{C}-\mathrm{O}-\mathrm{C}) .{ }^{1} \mathrm{H}-\mathrm{NMR}\left(\mathrm{CD}_{3} \mathrm{OD}\right.$, $500 \mathrm{MHz}) \delta / \mathrm{ppm}=6.67(1 \mathrm{H}, \mathrm{dd}, J=8.31$ and $2.23 \mathrm{~Hz}, \mathrm{H} 4), 6.78(1 \mathrm{H}, \mathrm{dd}, J=8.31$ and $2.23 \mathrm{~Hz}, \mathrm{H} 2), 6.84(1 \mathrm{H}, \mathrm{d}$, $J=8.94 \mathrm{~Hz}, \mathrm{H} 7), 7.51(1 \mathrm{H}, \mathrm{t}, J=8.31 \mathrm{~Hz}, \mathrm{H} 3), 7.97(1 \mathrm{H}, \mathrm{d}, J=8.94 \mathrm{~Hz}, \mathrm{H} 8) .{ }^{13} \mathrm{C}-\mathrm{NMR}\left(\mathrm{CD}_{3} \mathrm{OD}, 125 \mathrm{MHz}\right) \delta /$ $\mathrm{ppm}=103.4(\mathrm{C} 4), 107.8(\mathrm{C} 8 \mathrm{~b}), 109.4(\mathrm{C} 2), 110.9(\mathrm{C} 7), 113.2(\mathrm{C} 8 \mathrm{a}), 116.6(\mathrm{C} 8), 128.3(\mathrm{C} 5), 137.0(\mathrm{C} 3), 157.7$ (C4b), 160.1 (C6), 162.9 (C4a), 169.4 (C1), 182.3 (C9). MS $m / z=228[\mathrm{M}-16]^{+}$.

In vitro antioxidant assay. The antioxidant activity of hydroxyxanthones was evaluated by using a DPH scavenging assay. Each hydroxyxanthone (3a-c) was dissolved in methanol at a concentration range from 10 to 

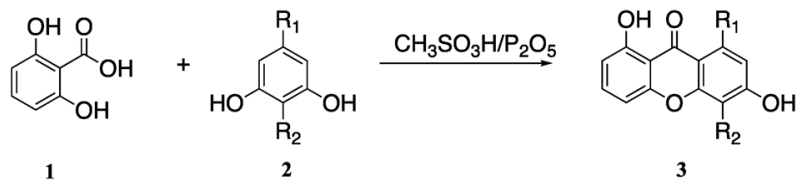

(a) $\mathrm{R}_{1}=\mathrm{OH}, \mathrm{R}_{2}=\mathrm{H}$

(b) $\mathrm{R}_{1}=\mathrm{R}_{2}=\mathrm{H}$

(c) $\mathrm{R}_{1}=\mathrm{H}, \mathrm{R}_{2}=\mathrm{OH}$

Figure 1. Synthesis scheme of hydroxyxanthone derivatives.

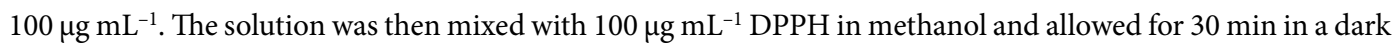
condition. The absorbance value of the absorption signal at $517 \mathrm{~nm}$ was measured using a UV-Vis spectrophotometer (Shimadzu UV 1800). The radical scavenging percentage was calculated using Eq. (1), whereas $A_{\text {blank }}$ and $\mathrm{A}_{\text {sample }}$ are the absorbances at $517 \mathrm{~nm}$ for blank (methanol) and sample (hydroxyxanthone), respectively.

$$
\% \text { Radical scavenging }=\left(\mathrm{A}_{\text {blank }}-\mathrm{A}_{\text {sample }}\right) /\left(\mathrm{A}_{\text {blank }}\right) \times 100 \%
$$

Afterward, the radical scavenging percentage was plotted versus the concentration of the antioxidant agent. The half-maximal inhibitory concentration $\left(\mathrm{IC}_{50}\right)$ value was calculated by fixing the radical scavenging percentage equal to $50 \%$. The in vitro antioxidant assay for each sample was performed in three replications.

In vitro anticancer assay. The in vitro anticancer activity of hydroxyxanthones was evaluated by using the MTT method. All cancer and normal (Vero) cell lines were supplied by the Parasitology Laboratory, Universitas Gadjah Mada, Indonesia. The cells were cultured at $37^{\circ} \mathrm{C}$ in an incubator containing $5 \% \mathrm{CO}_{2}$. Briefly, the WiDr (colorectal cancer), MCF-7 (breast cancer), and HeLa (cervical cancer) cells were suspended in medium with $10 \%$ Fetal Bovine Serum. Concisely, the cell lines were added to 96-well plates and cultured in a medium with various concentrations of each hydroxyxanthone $3 \mathbf{a}-\mathbf{c}$. The mixture was stored in a $\mathrm{CO}_{2}$ incubator. After $24 \mathrm{~h}$, the MTT reagent was added, and the mixture was further incubated for an additional $3 \mathrm{~h}$. Afterward, the sodium dodecyl sulfate (SDS) page was added to the mixture, and the mixture was re-incubated for $24 \mathrm{~h}$ in a darkroom. The absorbance value of the solution at $495 \mathrm{~nm}$ was measured using an Elisa reader (Benchmark) to calculate viability cells' percentage (Eq. 2).

$$
\% \text { Viability cells }=\left(\mathrm{A}_{\text {blank }}-\mathrm{A}_{\text {sample }}\right) /\left(\mathrm{A}_{\text {blank }}\right) \times 100 \%
$$

Afterward, the viability cells' percentage was plotted versus the concentration of the anticancer agent. The $\mathrm{IC}_{50}$ value was calculated by fixing the viability cells' percentage equals $50 \%$. The in vitro anticancer assay for each sample was performed in three replications.

Molecular docking study of hydroxyxanthone derivative as an anticancer agent. The human Topoisomerase II with $4 \mathrm{G} 0 \mathrm{~V}$ as the protein code was retrieved from the Protein Data Bank. At first, the water molecules were removed from the Topoisomerase II protein structure. Then, the hydrogen atoms were added to build up the structure of the Topoisomerase II protein using AutoDock Tools software. The molecular docking process was performed by using AutoDock Vina software. The validity of the molecular docking study is represented by the root-mean-square deviation (RMSD) value less than $2.0 \AA^{34}$. Finally, the formed interactions between hydroxyxanthone and the active site of Topoisomerase II protein were visualized by using Discovery Studio software.

\section{Results and discussion}

Synthesis of hydroxyxanthone derivatives. The synthesis scheme of hydroxyxanthone derivatives in this work is shown in Fig. 1. All hydroxyxanthones $(\mathbf{3 a}-\mathbf{c})$ were prepared through a cyclo-acylation reaction of 2,6-dihydroxybenzoic acid (1) with phenolic derivatives $(\mathbf{2 a}-\mathbf{c})$. From the spectroscopic elucidation, the correct chemical structure of hydroxyxanthones $\mathbf{3 a}-\mathbf{c}$ has been confirmed. The FTIR, MS, ${ }^{1} \mathrm{H}-$, and ${ }^{13} \mathrm{C}-\mathrm{NMR}$ spectra of hydroxyxanthones $\mathbf{3 a - c}$ are depicted in Figs. S1-S12. In general, the FTIR spectra of hydroxyxanthones showed the appearance of $\mathrm{O}-\mathrm{H}$ hydroxyl groups at $3425-3448 \mathrm{~cm}^{-1}$ while the $\mathrm{C}=\mathrm{O}$ functional group appeared as a sharp signal at $1604-1612 \mathrm{~cm}^{-1}$. On the other hand, the $\mathrm{C}=\mathrm{C}$ aromatic and $\mathrm{C}-\mathrm{O}-\mathrm{C}$ heterocyclic moieties were observed at 1418-1465 and 1273-1296 $\mathrm{cm}^{-1}$, respectively (Figs. S1, S5, and S9). Another evidence to prove the successful production of hydroxyxanthones was the presence of molecular ion fragments $\left([\mathrm{M}]^{+}\right)$in their MS spectra (Figs. S2, S6, and S10). Hydroxyxanthones 3a and 3c showed five aromatic protons, while hydroxyxanthone $3 \mathbf{b}$ showed six aromatic protons in the range of 6.09-7.99 ppm in their ${ }^{1} \mathrm{H}-\mathrm{NMR}$ spectra (Figs. S3, S7, and S11). Meanwhile, the presence of carbon atoms of the carbonyl group of hydroxyxanthones 3a-c was found at 185.1, 181.9, and $182.3 \mathrm{ppm}$, respectively, in their ${ }^{13} \mathrm{C}-\mathrm{NMR}$ spectra (Figs. S4, S8, and S12). These spectroscopic data demonstrated that hydroxyxanthones had been successfully synthesized in this work.

Antioxidant activity assay of hydroxyxanthones. Antioxidant activity assay of hydroxyxanthones 3a-c was performed by using DPPH free radicals method as the most common procedure. The antioxidant activity of hydroxyxanthones was shown in the term $\mathrm{IC}_{50}$ value (Table 1 ). A lower $\mathrm{IC}_{50}$ value means a higher 


\begin{tabular}{|l|l|}
\hline Compound & IC $_{50}(\boldsymbol{\mu M})$ \\
\hline 3a & $653 \pm 53$ \\
\hline 3b & $349 \pm 68$ \\
\hline 3c & $524 \pm 72$ \\
\hline BHT & $40 \pm 4$ \\
\hline
\end{tabular}

Table 1. In vitro antioxidant activity of hydroxyxanthone derivatives.

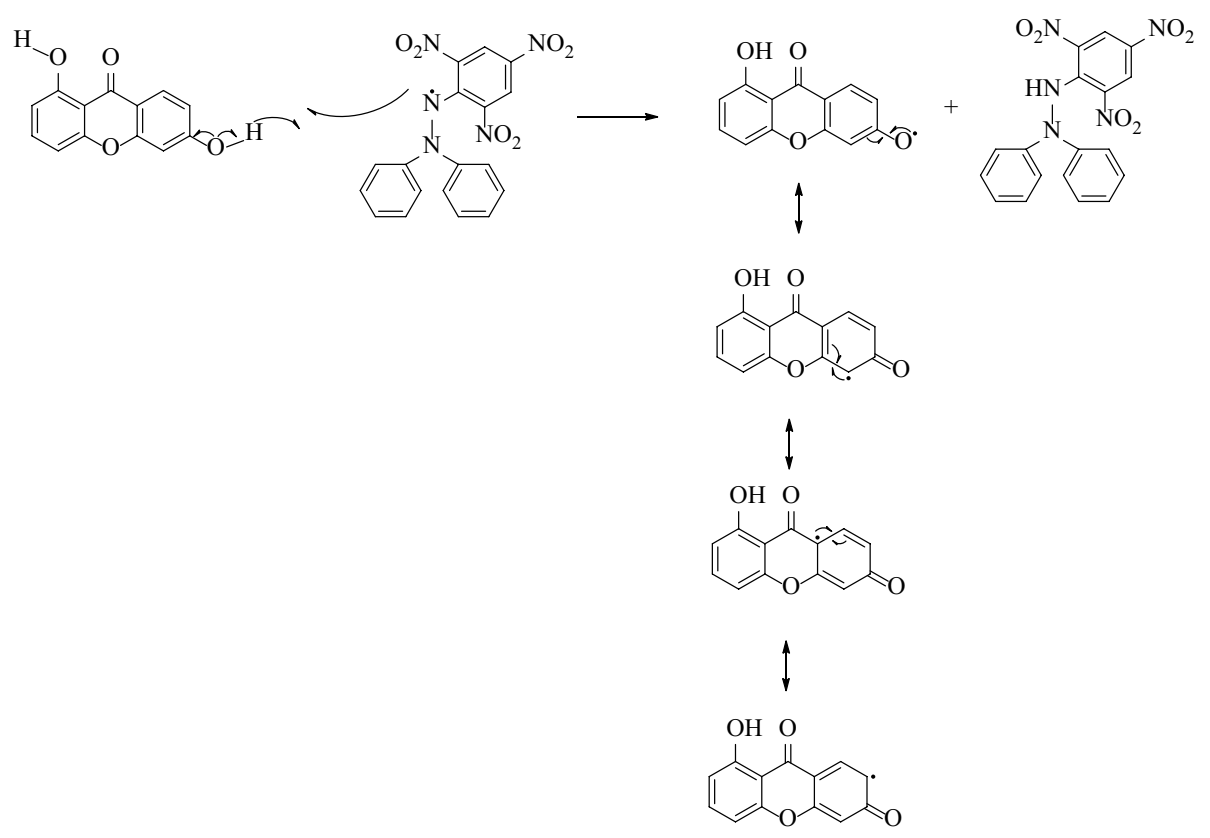

Figure 2. The plausible reaction of DPPH free radical with dihydroxyxanthone $\mathbf{3 b}$.

\begin{tabular}{|l|l|l|l|l|}
\hline \multirow{2}{*}{ Compound } & $\mathrm{IC}_{\mathbf{5 0}}(\boldsymbol{\mu M})$ & & & \\
\cline { 2 - 5 } & Vero $^{39}$ & MCF-7 & WiDr & HeLa \\
\hline 3a & $3395 \pm 435$ & $184 \pm 15$ & $254 \pm 15$ & $277 \pm 9$ \\
\hline 3b & $308 \pm 35$ & $450 \pm 17$ & $355 \pm 24$ & $322 \pm 4$ \\
\hline 3c & $224 \pm 14$ & $419 \pm 27$ & $209 \pm 4$ & $241 \pm 13$ \\
\hline Doxorubicin & $150 \pm 3$ & $71 \pm 6$ & $3 \pm 0.2$ & - \\
\hline Cisplatin & - & - & - & $142 \pm 52$ \\
\hline
\end{tabular}

Table 2. In vitro anticancer activity of hydroxyxanthone derivatives.

antioxidant activity of hydroxyxanthones. Although all hydroxyxanthones gave a lower antioxidant activity than $\mathrm{BHT}$ as the positive control, the trihydroxyxanthones (compounds $\mathbf{3 a}$ and $\mathbf{3 c}$ ) gave higher $\mathrm{IC}_{50}$ values than the dihydroxyxanthone $\mathbf{3 b}$. It shows that a higher amount of hydroxyl groups on the xanthone structure gave a lower antioxidant activity due to a stronger hydrogen bonding among the hydroxyl groups as previously reported ${ }^{35,36}$. Dihydroxyxanthone $\mathbf{3 b}$ exhibited the strongest antioxidant activity $\left(\mathrm{IC}_{50}=349 \pm 68 \mu \mathrm{M}\right)$. Since the hydroxyl groups were located far from each other, the DPPH free radicals could easily attack the hydroxyl groups of dihydroxyxanthone $\mathbf{3 b}$, yielding a strong antioxidant activity. This phenomenon was in agreement with the previous report $^{37}$. The plausible reaction mechanism of DPPH free radicals with dihydroxyxanthone $3 \mathbf{b}$ is shown in Fig. 2. This reaction mechanism generated a product with high resonance stability which could be responsible for the high antioxidant activity of dihydroxyxanthone $\mathbf{3 b}$.

Anticancer activity assay of hydroxyxanthones. Evaluation of the anticancer activity of hydroxyxanthones was conducted through the MTT assay. The anticancer activity of hydroxyxanthones was represented in the term of $\mathrm{IC}_{50}$ value (see Table 2 ). A lower $\mathrm{IC}_{50}$ value reflects a stronger anticancer activity of hydroxyxantho- 


\begin{tabular}{|l|c|c|c|}
\hline Compound & MCF-7 & WiDr & HeLa \\
\hline 3a & 18.42 & 13.39 & 12.25 \\
\hline 3b & 0.686 & 0.870 & 0.959 \\
\hline 3c & 0.535 & 1.072 & 0.931 \\
\hline
\end{tabular}

Table 3. Selectivity index of hydroxyxanthone derivatives as anticancer agent.

\begin{tabular}{|c|c|c|c|}
\hline \multirow[b]{2}{*}{ Compound } & \multirow{2}{*}{\begin{tabular}{|l|}
$\mathrm{IC}_{50}(\mu \mathrm{M})$ \\
$\mathrm{WiDr}$ \\
\end{tabular}} & \multirow[b]{2}{*}{ SI } & \multirow[b]{2}{*}{ Reference } \\
\hline & & & \\
\hline 1,3,8-trihydroxyxanthone (3a) & $254 \pm 15$ & 13.39 & \multirow{3}{*}{ This work } \\
\hline 1,6-dihydroxyxanthone (3b) & $355 \pm 24$ & 0.870 & \\
\hline 1,5,6-trihydroxyxanthone (3c) & $209 \pm 4$ & 1.072 & \\
\hline 1,3-dihydroxyxanthone & $836 \pm 109$ & 2.230 & \multirow{5}{*}{33} \\
\hline 3,4-dihydroxyxanthone & $1255 \pm 105$ & 1.160 & \\
\hline 3,6-dihydroxyxanthone & $786 \pm 146$ & 1.630 & \\
\hline 1,3,6-trihydroxyxanthone & $384 \pm 93$ & 1.540 & \\
\hline 3,4,6-trihydroxyxanthone & $38 \pm 11$ & 66.39 & \\
\hline
\end{tabular}

Table 4. Comparison of in vitro anticancer activity of hydroxyxanthone derivatives against WiDr cancer cell line.

nes. Even though the anticancer activity of hydroxyxanthones was weaker than either doxorubicin or cisplatin as the positive control, the anticancer activity of hydroxyxanthones was still categorized as medium activity.

Among the prepared hydroxyxanthones, hydroxyxanthone $\mathbf{3 a}$ was found as the best anticancer agent against the MCF-7 cell line $\left(\mathrm{IC}_{50}=184 \pm 15 \mu \mathrm{M}\right)$ while hydroxyxanthone $3 \mathrm{c}$ was the most active anticancer agent against $\mathrm{WiDr}\left(\mathrm{IC}_{50}=209 \pm 4 \mu \mathrm{M}\right)$ and $\mathrm{HeLa}\left(\mathrm{IC}_{50}=241 \pm 13 \mu \mathrm{M}\right)$ cell lines. These results demonstrated that trihydroxyxanthones were more active as the anticancer agent than dihydroxyxanthone $\mathbf{3 b}$. However, trihydroxyxanthone $3 \mathrm{c}$ was more toxic to normal Vero cell lines $\left(\mathrm{IC}_{50}=224 \pm 14 \mu \mathrm{M}\right)$ rather than either MCF-7 $\left(\mathrm{IC}_{50}=419 \pm 27 \mu \mathrm{M}\right)$ or HeLa $\left(\mathrm{IC}_{50}=241 \pm 13 \mu \mathrm{M}\right)$ cell lines. In contrast, trihydroxyxanthone 3a was more toxic to MCF-7 $\left(\mathrm{IC}_{50}=184 \pm 15 \mu \mathrm{M}\right)$, WiDr $\left(\mathrm{IC}_{50}=254 \pm 15 \mu \mathrm{M}\right)$, and $\mathrm{HeLa}\left(\mathrm{IC}_{50}=277 \pm 9 \mu \mathrm{M}\right)$ cancer cell lines rather than normal Vero cell line $\left(\mathrm{IC}_{50}=3395 \pm 435 \mu \mathrm{M}\right)$, which was remarkable.

Good anticancer drug candidates must be selective, i.e., toxic only to cancer cells but safe for normal cell lines ${ }^{38}$. The selectivity index (SI) was a critical parameter to describe selective anticancer activity. The SI value was calculated by dividing the $\mathrm{IC}_{50}$ of Vero cell lines with $\mathrm{IC}_{50}$ of cancer cells of hydroxyxanthone $\mathbf{3 a}-\mathbf{c}$. A higher SI value describes a more selective anticancer agent. The SI value of hydroxyxanthones $\mathbf{3 a}-\mathbf{c}$ is listed in Table 3. Compound 3a was found as the most selective anticancer agent due to its highest SI value against MCF-7, WiDr, and HeLa cancer cell lines among the other hydroxyxanthones in this work.

Table 4 compares the anticancer activity of hydroxyxanthones $3 \mathbf{a}-\mathbf{c}$ and the previously reported hydroxyxanthones against WiDr cancer cell line. Compared to the other hydroxyxanthone derivatives, dihydroxyxanthones $\left(\mathrm{IC}_{50}=355-1255 \mu \mathrm{M}\right)$ gave higher $\mathrm{IC}_{50}$ values than trihydroxyxanthones $\left(\mathrm{IC}_{50}=38-384 \mu \mathrm{M}\right)$. Among the dihydroxyxanthones, the order of the anticancer activity against the WiDr cancer cell line was 1,6-dihydroxyxanthone $>3,6$-dihydroxyxanthone $>1,3$-dihydroxyxanthone $>3,4$-dihydroxyxanthone. Meanwhile, the order of the anticancer activity of trihydroxyxanthones was 3,4,6-trihydroxyxanthone $>1,5,6$-trihydroxyxanthone $>1,3,8$-trihydroxyxanthone $>$ 1,3,6-trihydroxyxanthone. From the reported quantitative structure-activity relationship (QSAR) study, we found that the $\mathrm{IC}_{50}$ value of hydroxyxanthone as the anticancer agent against WiDr cancer cell line depends on the net atomic charge on carbon atoms, dipole moment, and octanol/water partition coefficient ${ }^{33}$. Furthermore, the SI values of trihydroxyxanthones against WiDr cells $(\mathrm{SI}=1.072-66.39)$ are higher than the dihydroxyxantones $(\mathrm{SI}=0.870-2.230)$, demonstrating that trihydroxyxanthones are more potential anticancer drug candidates than dihydroxyxanthones.

Molecular docking study on the inhibition of topoisomerase II protein by hydroxyxanthones. The experimental in vitro assay found that hydroxyxanthone $\mathbf{3 a}$ exhibited the strongest and the most selective anticancer activity among the other hydroxyxanthones in this work. Therefore, a further investigation was conducted for hydroxyxanthone 3a through a molecular docking study to reveal the inhibition mechanism on the active site of Topoisomerase II protein. Topoisomerase II protein is selected as the target protein since Topoisomerase II serves a pivotal role in the DNA replication and transcription of cancer cells. Doxorubicin is an anticancer agent with strong inhibitory activity towards Topoisomerase II protein. Doxorubicin consists of two fused aromatics with a carbonyl structure, which is similar to the prepared hydroxyxanthone $\mathbf{3 a}$.

The formed interactions from the molecular docking study are displayed in Fig. 3. Several interactions were observed between hydroxyxanthone 3a with the DNA chains of Topoisomerase II, such as hydrogen bond with DG13, as well as $\pi-\pi$ stacking with DA12 and DC8. These kinds of interactions have been reported to be critical for the inhibitory activity against Topoisomerase II protein. Etoposide, a standard Topoisomerase inhibitor, was 
(a)

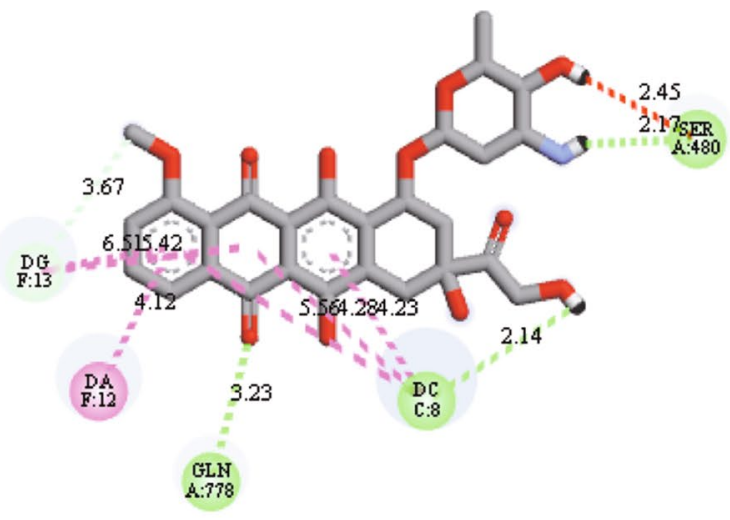

(b)

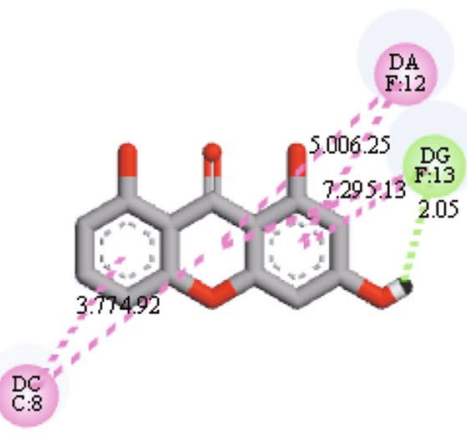

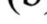

Interactions

Conventional Hydrogen Bond
Interactions

Conventional Hydrogen Bond

Carbon Hydrogen Bond
Unfavorable Donor-Donor

Pi-Pi Stacked

Figure 3. Visualization of the intermolecular interactions of (a) doxorubicin and (b) hydroxyxanthone 3a with the active sites of topoisomerase II.

reported to generate hydrogen bond interactions with Asp463 and DG13 on the active site of Topoisomerase $\mathrm{II}^{40}$. On the other hand, the binding interaction of the anticancer agent with DG13 was reported as pivotal interaction as this interaction stimulates the formation of DNA damage that is toxic to cancer cells ${ }^{41}$. Similar binding modes with DA12 and DC8 through $\pi-\pi$ stacking were also reported for the most active benzoxazole and olivacine derivatives as the anticancer agents $\mathrm{s}^{40,42}$.

On the other side, doxorubicin interacted to the active site of Topoisomerase II through hydrogen bond (Ser480, DC8, Gln778), carbon-hydrogen bond (DG13), and $\pi-\pi$ stacking (DG13, DA12, DC8) interactions. Compared to doxorubicin, hydroxyxanthone 3a generated no interaction with Ser480 and Gln778. Therefore, the theoretical binding energy and binding constant of hydroxyxanthone $3 \mathbf{a}$ were lower than doxorubicin. The binding energy and binding constant of hydroxyxanthone 3a with Topoisomerase II were $-8.0 \mathrm{kcal} \mathrm{mol}^{-1}$ and $1.362 \mu \mathrm{M}$, respectively, which were weaker than doxorubicin $\left(-8.9 \mathrm{kcal} \mathrm{mol}^{-1}, 0.299 \mu \mathrm{M}\right)$. Nevertheless, it is worthy to note that hydroxyxanthone 3 a was able to disturb the function of Topoisomerase II protein, thus increasing the cell apoptosis, which led to the death of cell cancers as previously reported ${ }^{31}$.

\section{Conclusions}

Three hydroxyxanthones (3a-c) have been successfully synthesized from 2,6-dihydroxybenzoic acid and phenolic compounds through an acylation reaction using Eaton's reagent. The chemical structures of hydroxyxanthones have been clearly elucidated by using FTIR, MS, ${ }^{1} \mathrm{H}$-, and ${ }^{13} \mathrm{C}-\mathrm{NMR}$. The in vitro antioxidant assay showed that trihydroxyxanthones $\mathbf{3 a}$ and $\mathbf{3} \mathbf{c}$ gave higher $\mathrm{IC}_{50}$ values than dihydroxyxanthone $\mathbf{3 b}$ due to stronger hydrogen bonds. It was found that dihydroxyxanthone $\mathbf{3 b}$ exhibited the strongest antioxidant activity $\left(\mathrm{IC}_{50}=349 \pm 68 \mu \mathrm{M}\right)$. On the other hand, trihydroxyxanthones gave higher anticancer activity than the dihydroxyxanthone one. Trihydroxyxanthone $3 \mathbf{a}$ exhibited higher toxicity against MCF-7 $\left(\mathrm{IC}_{50}=184 \pm 15 \mu \mathrm{M}\right)$, WiDr $\left(\mathrm{IC}_{50}=254 \pm 15 \mu \mathrm{M}\right)$, and $\mathrm{HeLa}\left(\mathrm{IC}_{50}=277 \pm 9 \mu \mathrm{M}\right)$ cancer cell lines rather than normal Vero cells $\left(\mathrm{IC}_{50}=3395 \pm 435 \mu \mathrm{M}\right)$. Consequently, trihydroxyxanthone 3a yielded the highest selectivity index (12.25-18.42) among the prepared hydroxyxanthones in this work. The molecular docking study reveals that hydrogen bond and $\pi-\pi$ stacking interactions were observed between trihydroxyxanthone $\mathbf{3 a}$ with the DNA chains of Topoisomerase II. The trihydroxyxanthone 3a was able to disturb the function of Topoisomerase II protein. These findings are important for the future development of anticancer agents based on hydroxyxanthone derivatives.

\section{Data availability}

The datasets generated during and/or analyzed in the current study are available from the corresponding author upon a reasonable request.

Received: 20 September 2021; Accepted: 14 January 2022

Published online: 27 January 2022

\section{References}

1. Liguori, I. et al. Oxidative stress, aging, and diseases. Clin. Interv. Aging 13, 757-772. https://doi.org/10.2147/CIA.S158513 (2018).

2. Gutteridge, J. M. C. \& Halliwell, B. Mini-review: Oxidative stress, redox stress or redox success?. Biochem. Biophys. Res. Commun. 502, 183-186. https://doi.org/10.1016/j.bbrc.2018.05.045 (2018).

3. Phaniendra, A., Jestadi, D. B. \& Periyasamy, L. Free radicals: Properties, sources, targets, and their implication in various diseases. Indian J. Clin. Biochem. 30, 11-26. https://doi.org/10.1007/s12291-014-0446-0 (2015).

4. Estenbauer, H., Rothemeder, M. D. \& Waeg, G. Role of vitamin E in preventing the oxidant of low density lipoprotein. Am. J. Clin. Nutr. 53, 314-321. https://doi.org/10.1093/ajcn/53.1.314S (1991). 
5. Neha, K., Haider, M. R., Pathak, A. \& Yar, M. S. Medicinal prospects of antioxidants: A review. Eur. J. Med. Chem. 178, 687-704. https://doi.org/10.1016/j.ejmech.2019.06.010 (2019).

6. Gulcin, I. Antioxidants and antioxidant methods: An updated overview. Arch. Toxicol. 94, 651-715. https://doi.org/10.1007/s1s00 204-020-02689-3 (2020).

7. Sindhi, V. et al. Potential applications of antioxidants - A review. J. Pharm. Res. 7, 828-835. https://doi.org/10.1016/j.jopr.2013.10. $001(2013)$

8. Lourenco, S. C., Moldao-Martins, M. \& Alves, V. D. Antioxidants of natural plant origins: From sources to food industry applications. Molecules 24, 4132. https://doi.org/10.3390/molecules24224132 (2019).

9. Kanwal, K. et al. Indole-3-acetamides: As potential antihyperglycemic and antioxidant agents; synthesis, in vitro $\alpha$-amylase inhibitory activity, structure-activity relationship, and in silico studies. ACS Omega 6, 2264-2275. https://doi.org/10.1021/acsomega. 0c05581 (2021).

10. Qureshi, F., et al. Synthesis and characterization of cadmium-bismuth microspheres for the catalytic and photocatalytic degradation of organic pollutants, with antibacterial, antioxidant and cytotoxicty assay. J. Photochem. Photobiol. B Biol. 202, 111723. https:// doi.org/10.1016/j.jphotobiol.2019.111723 (2020).

11. Rafique, R. et al. Synthesis, in vitro $\alpha$-amylase inhibitory, and radicals (DPPH \& ABTS) scavenging potentials of new $N$-sulfonohydrazide substituted indazoles. Bioorg. Chem. 94, 103410. https://doi.org/10.1016/j.bioorg.2019.103410 (2020).

12. Jamil, W. et al. Syntheses, characterization, in vitro antiglycation and DPPH radical scavenging activities of isation salicylhydrazidehydrazone and its $\mathrm{Mn}(\mathrm{II}), \mathrm{Co}(\mathrm{II}), \mathrm{Ni}(\mathrm{II}), \mathrm{Cu}(\mathrm{II})$, and $\mathrm{Zn}(\mathrm{II})$ metal complexes. Arab. J. Chem. 12, 2262-2269. https://doi.org/10. 1016/j.arabjc.2015.02.015 (2019)

13. Silva, V. et al. 1,2-Dihydroxyxanthone: Effect on A375-C5 melanoma cell growth associated with interference with THP-1 human macrophage activity. Pharmaceuticals 12, 85. https://doi.org/10.3390/ph12020085 (2019).

14. Castanheiro, R. A. P., Silva, A. M. S., Campos, N. A. N., Nascimento, M. S. J. \& Pinto, M. M. M. Antitumor activity of some prenylated xanthones. Pharmaceuticals 2, 33-43. https://doi.org/10.3390/ph2020033 (2009).

15. Lippold, T., Neudorfl, J. M. \& Griesbeck, A. New acridone- and (thio)xanthone-derived 1,1-donor-acceptor-substituted alkenes: pH-Dependent fluorescence and unusual photooxygenation properties. Molecules 26, 3305. https://doi.org/10.3390/molecules2 6113305 (2021).

16. Kurniawan, Y. S. et al. An update on the anticancer activity of xanthone derivatives: A review. Pharmaceuticals 14, 1144. https:// doi.org/10.3390/ph14111144 (2021).

17. Gunter, N. V., The, S. S., Lim, Y. M. \& Mah, S. H. Natural xanthones and skin inflammatory diseases: Multitargeting mechanisms of action and potential application. Front. Pharmacol. 11, 594202. https://doi.org/10.3389/fphar.2020.594202 (2020).

18. Shagufta, \& Ahmad, I. Recent insight into the biological activities of synthetic xanthone derivatives. Eur. J. Med. Chem. 116, 267-280. https://doi.org/10.1016/j.ejmech.2016.03.058 (2016).

19. Zhang, H. et al. Anticancer activity of dietary xanthone $\alpha$-mangostin against hepatocellular carcinoma by inhibition of STAT3 signaling via stabilization of SHP1. Cell Death Dis. 11, 63. https://doi.org/10.1038/s41419-020-2227-4 (2020).

20. Pinto, M. M. et al. From natural products to new synthetic small molecules: A journey through the world of xanthones. Molecules 26, 431. https://doi.org/10.3390/molecules26020431 (2021).

21. Franca, F. et al. A pyranoxanthone as a potent antimitotic and sensitizer of cancer cells to low doses of paclitaxel. Molecules 25, 5845. https://doi.org/10.3390/molecules25245845 (2020).

22. Nkengfack, E. A., Kounga, P. A., Fomun, T. Z., Meyer, M. \& Bodo, B. Glubixanthones A and B, two new cytotoxic xanthones with isoprenoid groups from the root bark of Symphonia globurifer. J. Nat. Prod. 65, 734-736. https://doi.org/10.1021/np010478w (2002).

23. Zarena, A. S. \& Sankar, K. U. Supercritical carbon dioxide extraction of xanthones with antioxidant activity from Garcinia mangostana: Characterization by HPLC/LC-ESI-MS. J. Supercrit. Fluids 49, 330-337. https://doi.org/10.1016/j.supflu.2009.03.004 (2009).

24. Loureiro, D. R. P. et al. Structures, activities and drug-likeness of anti-infective xanthone derivatives isolated from the marine environment: A review. Molecules 24, 243. https://doi.org/10.3390/molecules24020243 (2019).

25. Sousa, M. E. \& Pinto, M. M. M. Synthesis of xanthones: An overview. Curr. Med. Chem. 12, 2447-2479. https://doi.org/10.2174/ $092986705774370736(2005)$

26. Zhou, B. D. et al. Synthesis and antitumor, antityrosinase, and antioxidant activities of xanthone. J. Asian Nat. Prod. Res. 1, 1-10. https://doi.org/10.1080/10286020.2018.1454437 (2018).

27. Taha, M. et al. Synthesis, anticancer, molecular docking and QSAR studies of benzylhydrazone. J. Saudi Chem. Soc. 23, 1168-1179. https://doi.org/10.1016/j.jscs.2019.07.007 (2019).

28. Abbass, E. M., Khalil, A. K., Mohamed, M. M., Eissa, I. H. \& El-Naggar, A. M. Design, efficient synthesis, docking studies, and anticancer evaluation of new quinoxalines as potential intercalative topo II inhibitors and apoptosis inducers. Bioorg. Chem. 104, 104255. https://doi.org/10.1016/j.bioorg.2020.104255 (2020).

29. Ito, C. et al. Chemical constituents of Garcinia fusca: Structure elucidation of eight new xanthones and their cancer chemopreventive activity. J. Nat. Prod. 66, 200-205. https://doi.org/10.1021/np020290s (2003).

30. Kuete, V. et al. Cytotoxicity and modes of action of three naturally occuring xanthones (8-hydroxycudraxanthone G, murosignin I and cudraxanthone I) against sensitive and multi-drug-resistant cancer cell lines. Phytomedicine 21, 315-322. https://doi.org/ 10.1016/j.phymed.2013.08.018 (2014).

31. Jun, K. Y. et al. Synthesis, biological evaluation, and molecular docking study of 3-(3'-heteroatom substituted-2'-hydroxy-1'propyloxy) xanthone analogues as novel topoisomerase IIa catalytic inhibitor. Eur. J. Med. Chem. 46, 1964-1971. https://doi.org/ 10.1016/j.ejmech.2011.01.011 (2011).

32. Graves, D. E. \& Velea, L. M. Intercalative binding of small molecules to nucleic acids. Curr. Org. Chem. 4, 915-929. https://doi. org/10.2174/1385272003375978 (2000).

33. Miladiyah, I., Jumina, J., Haryana, S. M. \& Mustofa, M. Biological activity, quantitative structure-activity relationship analysis, and molecular docking of xanthone derivatives as anticancer drugs. Drug Des. Dev. Ther. 12, 149-158. https://doi.org/10.2147/DDDT. S149973 (2018).

34. Trott, O. \& Olson, A. J. AutoDock Vina: Improving the speed and accuracy of docking with new scoring function, efficient optimization and multithreading. J. Comput. Chem. 31, 455-461. https://doi.org/10.1002/jcc.21334 (2010).

35. Freitas, V. L. S. \& da Silva, M. D. M. C. R. Influence of hydroxyl functional group on the structure and stability of xanthone: A computational approach. Molecules 23, 2962. https://doi.org/10.3390/molecules23112962 (2018)

36. Jumina, J. et al. Development of C-arylcalix[4]resorcinarenes and C-arylcalix[4]pyrogallolarenes as antioxidant and UV-B protector. Indones. J. Chem. 19, 273-284. https://doi.org/10.22146/ijc.26868 (2019).

37. Franca, H. S., Rocha, L., Fernande, C. P., Ruis, A. L. T. \& Carvalho, J. E. Antiproliferative activity of the hexanic extract and phloroglucinols from Hypericum brasiliense. Rev. Bras. Pharmacogn. 23, 844-847. https://doi.org/10.1590/S0102-695X20130005000 18 (2013).

38. Khan, T. et al. Anticancer plants: A review of the active phytochemicals, applications in animal models, and regulatory aspects. Biomolecules 10, 47. https://doi.org/10.3390/biom100100471 (2020).

39. Zakiah, M. et al. In vitro antiplasmodial, heme polymerization, and cytotoxicity of hydroxyxanthone derivatives. J. Trop. Med. 2021, 8866681. https://doi.org/10.1155/2021/8866681 (2021).

40. Tylinska, B. et al. Evaluation of interactions of selected olivacine derivatives with DNA and topoisomerase II. Int. J. Mol. Sci. 22, 8492. https://doi.org/10.3390/ijms22168492 (2021). 
41. Lemke, K. et al. Induction of unique structural changes in guanine-rich DNA regions by the triazoloacridone C-13, a topoisomerase II inibitor with antitumor activities. Nucleic Acids Res. 33, 6034-6047. https://doi.org/10.1093/nar/gki904 (2005).

42. Oksuzoglu, E. et al. Antitumor activities on HL-60 human leukemia cell line, molecular docking, and quantum-chemical calculations of some sulfonamide-benzoxazoles. Artif. Cells Nanomed. Biotechnol. 45, 1388-1396. https://doi.org/10.1080/21691401.2016. 1241796 (2016).

\section{Acknowledgements}

The financial support from KEMENDIKBUD-RISTEK through the World Class Research grant for the budget year 2021-2023 is greatly acknowledged.

\section{Author contributions}

Conception and design: J. Acquisition data: N.F., C.A., H.D.P., and E.N.S. Analysis and interpretation of data: N.F., Y.S.K. and Y.P. Drafting the article, review and editing, N.F. and Y.S.K. All authors have read and approved to the final version of the manuscript.

\section{Competing interests}

The authors declare no competing interests.

\section{Additional information}

Supplementary Information The online version contains supplementary material available at https://doi.org/ 10.1038/s41598-022-05573-5.

Correspondence and requests for materials should be addressed to J.J.

Reprints and permissions information is available at www.nature.com/reprints.

Publisher's note Springer Nature remains neutral with regard to jurisdictional claims in published maps and institutional affiliations.

(c) (i) Open Access This article is licensed under a Creative Commons Attribution 4.0 International License, which permits use, sharing, adaptation, distribution and reproduction in any medium or format, as long as you give appropriate credit to the original author(s) and the source, provide a link to the Creative Commons licence, and indicate if changes were made. The images or other third party material in this article are included in the article's Creative Commons licence, unless indicated otherwise in a credit line to the material. If material is not included in the article's Creative Commons licence and your intended use is not permitted by statutory regulation or exceeds the permitted use, you will need to obtain permission directly from the copyright holder. To view a copy of this licence, visit http://creativecommons.org/licenses/by/4.0/.

(C) The Author(s) 2022 